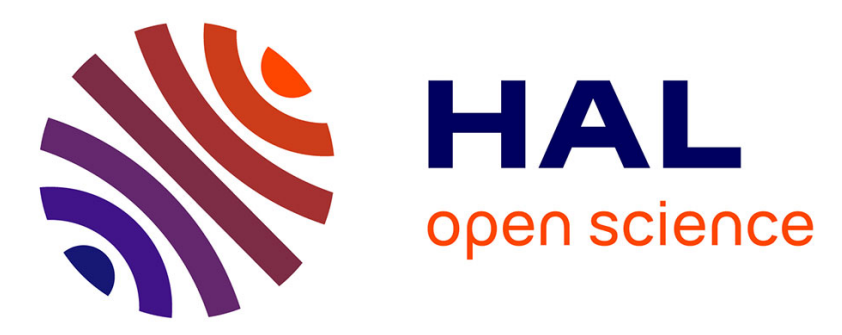

\title{
Modulation of leaf physiology by age and in response to abiotic constraints in young cuttings of two Populus deltoides x P. nigra genotypes
}

\author{
Nicolas Marron, Franck Brignolas, Francis Delmotte, Erwin Dreyer
}

\section{To cite this version:}

Nicolas Marron, Franck Brignolas, Francis Delmotte, Erwin Dreyer. Modulation of leaf physiology by age and in response to abiotic constraints in young cuttings of two Populus deltoides $\mathrm{x}$ P. nigra genotypes. Annals of Forest Science, 2008, 65 (404), n.p. 10.1051/forest:2008016 . hal-02654247

\section{HAL Id: hal-02654247 \\ https://hal.inrae.fr/hal-02654247}

Submitted on 29 May 2020

HAL is a multi-disciplinary open access archive for the deposit and dissemination of scientific research documents, whether they are published or not. The documents may come from teaching and research institutions in France or abroad, or from public or private research centers.
L'archive ouverte pluridisciplinaire HAL, est destinée au dépôt et à la diffusion de documents scientifiques de niveau recherche, publiés ou non, émanant des établissements d'enseignement et de recherche français ou étrangers, des laboratoires publics ou privés. 


\title{
Modulation of leaf physiology by age and in response to abiotic constraints in young cuttings of two Populus deltoides $\times P$. nigra genotypes
}

\author{
Nicolas MARron ${ }^{1,2}$, Franck BrignOLAS $^{1 *}$, Francis M. DELMOTTE $^{1}$, Erwin DrEYER $^{2}$ \\ ${ }^{1}$ Laboratoire de Biologie des Ligneux et des Grandes Cultures, UPRES EA 1207, UFR-Faculté des Sciences, Université d'Orléans, \\ rue de Chartres, BP 6759, 45067 Orléans Cedex 02, France \\ ${ }^{2}$ UMR INRA-UHP, Écologie et Écophysiologie Forestières, INRA Nancy, 54280 Champenoux, France
}

(Received 5 November 2007; accepted 8 January 2008)

\begin{abstract}
-
- It is of importance, when comparing physiological responses of leaves to environmental constraints among different genotypes, to take into account any effect related to leaf position and age within the canopy that might interfere with the response to the constraints.

- To document such effects, photosynthetic capacity and tolerance to heat and to oxidation were measured on leaves from the top to the bottom of three-month-old single-stem rooted cuttings of Populus deltoides $\times$ P. nigra genotypes, 'Dorskamp' and 'Luisa_Avanzo', thus taking into account a gradient of ages from youngest and still expanding (top) to oldest and fully expanded (bottom) leaves.

- All recorded traits were tightly linked to the age of the leaves. Photosynthetic capacity gradually increased during leaf expansion, in parallel with chlorophyll content and relative nitrogen allocation to RuBisCO and to bioenergetics. On the contrary, dark respiration gradually decreased during leaf expansion until a minimum value was reached at maturity. Compared to expanding leaves, young mature leaves were characterized by a lower sensitivity to heat and a higher one to oxidations generated by methyl-viologen.

- Leaf characteristics appeared to vary along the stem to a larger extent than between the two genotypes that display largely different productivities in plantations.
\end{abstract}

P. deltoides $\times$ P. nigra / leaf age / leaf position / photosynthetic capacities / thermotolerance / oxidation tolerance

Résumé - Modulation par l'âge et en réponse à des contraintes abiotiques de la physiologie des feuilles de jeunes boutures de deux génotypes de Populus deltoides $\times$ P. nigra.

- Pour comparer de manière fiable la réponse physiologique de feuilles de différents génotypes aux contraintes abiotiques, il est important de prendre en compte les effets liés à la position et à l'âge des feuilles au sein de la canopée pouvant interférer avec la réponse à la contrainte.

-Afin de documenter de tels effets, les capacités photosynthétiques et la tolérance à la chaleur et aux oxydations ont été mesurées sur des feuilles réparties tout le long de la tige de boutures de 3 mois des génotypes de Populus deltoides $\times$ P. nigra, 'Luisa_Avanzo' et 'Dorskamp'.

-Tous les traits mesurés présentaient une forte variabilité liée à l'âge des feuilles. Les capacités photosynthétiques augmentaient graduellement durant l'expansion foliaire, en parallèle avec les teneurs en chlorophylles et avec l'allocation d'azote à la RuBisCO et au transfert photosynthétique d'électrons. Au contraire, la respiration diminuait graduellement durant l'expansion foliaire jusqu'à ce qu'une valeur minimum soit atteinte à maturité de la feuille. En comparaison avec les feuilles en croissance, les jeunes feuilles matures étaient caractérisées par une tolérance plus grande à la chaleur et plus faible aux oxydations générées par du méthylviologène.

-Les caractéristiques foliaires variaient plus le long de la tige qu'entre les deux génotypes, pourtant connus pour leurs différences de niveau de productivité en plantation.

P. deltoides $\times$ P. nigra / âge des feuilles / position des feuilles / capacités photosynthétiques / thermotolérance / tolérance aux oxydations

Abbreviations - LPI: leaf plastochron index, $\boldsymbol{W}$ : leaf width $(\mathrm{cm}), \boldsymbol{A}$ : leaf area $\left(\mathrm{cm}^{2}\right)$, SLA: specific leaf area $\left(\mathrm{cm}^{2} \mathrm{~g}_{\text {DW }}^{-1}\right)$, A: assimilation rate $\left(\mu \mathrm{mol}_{\mathrm{CO} 2} \mathrm{~m}^{-2} \mathrm{~s}^{-1}\right), \mathbf{c}_{\mathrm{a}}$ : atmospheric $\mathrm{CO}_{2}$ partial pressure $(\mathrm{Pa}), \mathbf{c}_{\mathbf{i}}$ : partial pressure in the substomatal cavities (Pa), $\mathbf{J}_{\text {max }}$ : maximal light driven electron flow $\left(\mu \mathrm{mol}_{\mathrm{e}-} \mathrm{m}^{-2} \mathrm{~s}^{-1}\right), \mathbf{P}_{\mathrm{B}}$ : fraction leaf nitrogen invested into bioenergetics, $\mathbf{P}_{\mathrm{R}}$ : fraction leaf nitrogen invested into RuBisCO, $\mathbf{R}_{\mathbf{d}}$ : dark respiration $\left(\mu \mathrm{mol}_{\mathrm{CO} 2} \mathrm{~m}^{-2} \mathrm{~s}^{-1}\right), \mathbf{V}_{\mathrm{cmax}}$ : maximal carboxylation rate $\left(\mu \mathrm{mol}_{\mathrm{CO} 2} \mathrm{~m}^{-2} \mathrm{~s}^{-1}\right), \mathbf{V}_{\text {cmaxApp }}$ : apparent $\mathrm{V}_{\mathrm{cmax}}$, values not taking into account the internal conductance to $\mathrm{CO}_{2}$ transfer, $\mathbf{T}_{\mathbf{C}}$ : critical temperature for PS II stability $\left({ }^{\circ} \mathrm{C}\right), \mathbf{F}_{\mathbf{0}}$ : initial fluorescence, $\mathbf{F}_{\mathbf{m}}$ : maximal fluorescence, $\mathbf{F}_{\mathbf{v}}$ : variable fluorescence.

\section{INTRODUCTION}

A large number of physiological and genetic studies aiming at comparing poplar genotypes for their responses to envi-

* Corresponding author: franck.brignolas@univ-orleans.fr ronmental constraints are based on a range of leaf properties. These studies have been conducted with plant material ranging from small cuttings grown in a climate chamber under usually low irradiance, to young trees in the field, reaching 5-6 m during the second year of growth (Ceulemans and Isebrands, 1996; Dickson, 1986; Marron et al., 2002). It is well known 
that structural properties of leaves change in relation to their age, but also in relation to the age and the dimensions of the cutting itself (at constant leaf age). Nevertheless, it remains difficult to relate whole plant properties to specific changes in the structure and chemical composition of individual leaves (Dickson, 1986; Gonzalez-Real and Baille, 2000).

Structural and physiological leaf properties change significantly during development and ageing (Ceulemans et al., 1988; Ceulemans and Isebrands, 1996; Dickson, 1986). In a wide range of both herbaceous and woody species, specific leaf area (SLA) increases until final leaf size is attained and decreases during ageing as a result of increases in leaf thickness or density, or both (Marron et al., 2003; Niinemets 2001). Variations in organic compounds, such as mobile carbohydrates (soluble sugars in the cytosol and phloem sap), stored carbohydrates (fructans in the vacuole and starch in the chloroplast) and structural carbon (cell walls, lipids and proteins), can cause significant changes in SLA (Van Arendonk and Poorter, 1994). The decrease in SLA during leaf ageing has also been associated with cuticle thickening and secondary cell wall development, with adsorption and retention of calcium and other mineral elements (Zelawski and Walker, 1976), with tissue shrinkage or with continued cambial activity in mature leaf petioles (Isebrands and Larson, 1977).

For a large range of species, the rate of light-saturated net photosynthesis reaches its maximum at or slightly before full leaf area expansion (Miyazawa and Terashima, 2001). For Populus deltoides, Dickmann (1971) showed that photosynthesis of developing leaves increased till full leaf expansion, and declined in older leaves. Carbohydrate production and management are largely dependent on the leaf development stage. Expanding poplar leaves export carbon primarily upwards to younger leaves and the apex; fully expanded young leaves export it both upwards and downwards to the lower stem and roots; while mature leaves export it primarily downwards (Ceulemans and Isebrands, 1996; Dickson, 1986). This general pattern holds for poplar grown in controlled environment as well as in the field (Nelson and Isebrands, 1983), or under stress conditions (Coleman et al., 1996).

When assessing the effects of any treatment on leaf structure and physiology, the position on the plant (stage of development and degree of maturity) has to be taken into account as it may severely affect the leaf response. Poplar leaves belonging to different developmental stages indeed differ in their level of tolerance to environmental constraints such as drought, UV-B radiation or oxidations: mature leaves are usually more sensitive than expanding ones, the oldest ones usually displaying an accelerated senescence, with a resource remobilization before leaf fall (Schumaker et al., 1997). It has also been shown in poplar that leaf antioxidant activities as well as the leaf contents in both enzymatic and non enzymatic antioxidant compounds are closely linked to leaf development stage, the young mature leaves often showing the lowest activities and contents (Marron et al., 2002; 2006).

When referring to leaf growth or leaf age related processes in poplar, the leaf plastochron index (LPI) concept is usually applied as an elegant tool to express leaf age from a physiological point of view (Ceulemans et al., 1988, Erickson and
Michelini, 1957). LPI is a morphological scale that is a linear function of time. In the case of poplars that display linear growth and constant leaf initiation rates, LPI has been used extensively; nevertheless, these conditions are only fully met in controlled, constant environments (Ceulemans, 1990; Erickson and Michelini, 1957). During unstable conditions, such as during a drought for example, the foliar index (FI) should be used preferably (Marron et al., 2003).

The general objectives of this study were to illustrate and to understand the impact of leaf age and position on rooted cuttings, on a set of leaf traits and physiological processes in order to highlight the importance of taking such effects into account when comparing genotypes and their response to abiotic constraints. Two genotypes of Populus deltoides $\times P$. nigra, 'Luisa_Avanzo' and 'Dorskamp', were selected because they differ in growth and drought tolerance, as was observed during field and greenhouse experiments (Marron et al., 2002; 2003; Soulères, 1992). The specific objectives of the present study were: (1) to assess the relationships between leaf position along the stems and leaf structure (through leaf area and SLA), photosynthetic properties and contents in chlorophyll, nitrogen and carbon, and (2) to characterize the effects of two abiotic constraints (heat and oxidations) as a function of leaf position along the stems. To meet these objectives, the relationships between leaf position along the stem, on one hand, and leaf photosynthetic capacity, tolerance to heat and to photo-oxidations, on the other hand, were established using LPI as an index of leaf age.

\section{MATERIALS AND METHODS}

\subsection{Plant material}

Two-month-old, 20-cm long woody stem cuttings, from 2-yearold stems of Populus deltoides (Bartr.) Marsh. $\times$ P. nigra L. cv. 'Dorskamp' (male) and cv. 'Luisa_Avanzo' (female), were used in the experiments. During February 2001, 40 one-month-old rooted plants of each genotype were repotted into 4-L pots containing a mixture of blond and brown peat, horse manure, heather and bromide-disinfected compost (25:25:20:20:10, v/v, pH 5.8) (Falienor, Vivy, France). During April 2001, 14 homogeneous plants of each clone were selected to establish profiles of photosynthetic properties, chlorophyll, nitrogen and carbon contents ( 5 plants), tolerance to heat (5 plants), and to oxidations (4 plants) along the stem.

\subsection{Growth conditions}

Plants were placed in a greenhouse heated to $20{ }^{\circ} \mathrm{C}$, with an average spacing between the plants of $30 \mathrm{~cm}$, and exposed to natural daylight (transmitted maximal photon flux density in the photosynthetically active radiations was $600 \mu \mathrm{mol} \mathrm{m} \mathrm{m}^{-2} \mathrm{~s}^{-1}$ ), and were manually watered every second day. Leaves of each plant were numbered from the bottom to the top of the stem. The youngest leaf just exceeding $20 \mathrm{~mm}$ in length was indexed $\mathrm{n}$ (Larson and Isebrands, 1971). Leaf lengths were measured on all plants and LPI was computed from the equation of Erickson and Michelini (1957). Five plants were used to 
assess photosynthetic capacity and thermotolerance, and four for assessing the tolerance to oxidations. For photosynthetic capacity and thermotolerance, all leaves were analyzed up to the tenth leaf from the top, and every third leaf below. For oxidation tolerance, three leaf categories were analyzed: expanding (LPI $=1.9 \pm 0.2$ for 'Dorskamp' vs. $1.7 \pm 0.1$ for 'Luisa_Avanzo'), young mature (LPI $=8.6 \pm 0.3$ vs. $8.2 \pm 0.1$ ), and old leaves ( $\mathrm{LPI}=17.1 \pm 0.5$ vs. $17.4 \pm 0.4)$. Individual area of all leaves was estimated from the relationship: $\log A=a \log W$, where $A$ is leaf area, $W$ is leaf width and $a$ a coefficient equal to 1.73 and 1.81 for 'Dorskamp' and 'Luisa_Avanzo', respectively (Brignolas et al., 2000).

\subsection{Assessment of photosynthetic capacities}

Responses of net $\mathrm{CO}_{2}$ assimilation rate to $\mathrm{CO}_{2}$ partial pressure $\left(\mathrm{c}_{\mathrm{a}}\right)$ were recorded with an open path photosynthesis chamber LiCor 6400 (LiCor, Lincoln, Nebraska, USA) on fully light-induced leaves using the following procedure: increase of atmospheric $\mathrm{CO}_{2}$ partial pressure $\left(\mathrm{c}_{\mathrm{a}}\right)$ to $175 \mathrm{~Pa}$, and gradual decrease down to $5 \mathrm{~Pa}$ in 12 , six min long steps. At each step, net $\mathrm{CO}_{2}$ assimilation rate (A), stomatal conductance $\left(\mathrm{g}_{\mathrm{s}}\right)$, and the calculated $\mathrm{CO}_{2}$ partial pressure in the substomatal cavities $\left(c_{i}\right)$ were recorded after 4 min stabilisation. Each step consisted of three replications at $1 \mathrm{~min}$ intervals to check for stability. At the end of each response curve, illumination was switched off, and respiration due to phosphorylative oxidation $\left(\mathrm{R}_{\mathrm{d}}\right)$ was recorded at $35 \mathrm{~Pa} \mathrm{CO}_{2}$ after 5 min stabilisation. Maximal carboxylation rate $\left(\mathrm{V}_{\mathrm{cmaxApp}}, \mu \mathrm{mol}_{\mathrm{CO} 2} \mathrm{~m}^{-2} \mathrm{~s}^{-1}\right)$ and maximal light driven electron flow $\left(\mathrm{J}_{\max }, \mu \mathrm{mol}_{\mathrm{e}-} \mathrm{m}^{-2} \mathrm{~s}^{-1}\right)$ were estimated by adjusting Farquhar's model to the A- $\mathrm{c}_{\mathrm{i}}$ curves, as described in Dreyer et al. (2001). Internal conductance to $\mathrm{CO}_{2}$ transfer was not taken into account in this experiment; apparent values of $\mathrm{V}_{\mathrm{cmax}}$ displayed here $\left(\mathrm{V}_{\mathrm{cmax} A p p}\right)$ are therefore probably underestimates of real values of $\mathrm{V}_{\mathrm{cmax}}$ (Warren, 2006a).

Area based leaf chlorophyll content was measured with a SPAD502 chlorophyll meter (Minolta). The SPAD-502 was calibrated for our poplar leaves using the following procedure. Ten $\mathrm{mg}$ of freezedried leaf powder was suspended in $500 \mu \mathrm{L}$ of acetone:distilled water $(8: 2, \mathrm{v} / \mathrm{v})$. The mixture was subjected to an ultrasonic bath for $30 \mathrm{~min}$ at $4{ }^{\circ} \mathrm{C}$ and then centrifuged at $20000 \mathrm{~g}$ for $10 \mathrm{~min}$. The supernatant $(300 \mu \mathrm{L})$ was collected and the residue re-extracted once under the same conditions, and the recovered supernatants $(2 \times 300 \mu \mathrm{L})$ pooled. Chlorophyll was determined spectrophotometrically at $652 \mathrm{~nm}$ and chlorophyll concentration was calculated according to the McKinney equation (Marron et al., 2002; McKinney, 1941). Calibration equation was $x=9.907 y(r=0.89, P \leqslant 0.001)$, where $x$ is chlorophyll content expressed in $\mu$ mol per $\mathrm{m}^{-2}$ of leaf area and $y$ the SPAD-502 value. Total leaf nitrogen and carbon was measured in $1.5 \mathrm{mg}$ of powder with an elemental analyzer (2500 NCS, ThermoQuest, Finnigan CE Instruments, Waltham, MA) and expressed on a leaf dry weight basis $(\mathrm{C}$ and $\mathrm{N})$ and on a leaf area basis $(\mathrm{N})$. The fractions of total leaf nitrogen invested into RuBisCO $\left(\mathrm{P}_{\mathrm{R}}\right)$ and into bioenergetics $\left(\mathrm{P}_{\mathrm{B}}\right)$ were derived from $\mathrm{V}_{\text {cmaxApp }}$ and $\mathrm{J}_{\max }$ according to Niinemets and Tenhunen (1997).

\subsection{Critical temperature for photochemistry}

Response curves of $\mathrm{F}_{0}$ to a continuous temperature increase were recorded. Plants of each genotype were placed during $12 \mathrm{~h}$ in the dark at $20^{\circ} \mathrm{C}$ before the measurement. Disks ( $16 \mathrm{~mm}$ diameter) were punched sequentially from 13 leaves of each plant and placed into a temperature controlled aluminium body (Froux et al., 2004). Temperature was then increased gradually $\left(1^{\circ} \mathrm{C} \mathrm{min}^{-1}\right)$ from 20 to $60{ }^{\circ} \mathrm{C}$. Critical temperature for stability of photochemistry $\left(\mathrm{T}_{\mathrm{c}}\right)$ was recorded from the inflexion point at the beginning of the steep increase of $F_{0}$ (Bilger et al., 1984; Froux et al., 2004).

\subsection{Tolerance to photo-oxidations}

The herbicide paraquat (methyl-viologen) was used to artificially generate an oxidative constraint at leaf level. The herbicidal action of methyl-viologen in higher plants is the result of increased production of superoxide radicals, as it acts as a competitive electron acceptor at PS I donor side (Smirnoff, 1993). Methyl-viologen-generated $\mathrm{O}_{2}^{-}$ or its decomposition products, $\mathrm{H}_{2} \mathrm{O}_{2}$ and $\mathrm{OH}$, can initiate the breakdown of membrane lipids in thylakoids, in the chloroplast envelope, or other cellular membranes, and rapidly inhibit photosynthesis.

Four disks (16 mm diameter) per leaf were cut from the four plants of each genotype on expanding, young mature and old leaves. Disks were incubated during $14.5 \pm 2.5 \mathrm{~h}$ in Petri dishes, in the dark and at room temperature, with a $20 \mu \mathrm{M}$ methyl-viologen aqueous solution or with distilled water. Then, they were transferred to distilled water and exposed for $2 \mathrm{~h}$ to an actinic light source (sodium vapour halogen lamp; irradiance $500 \mu \mathrm{mol} \mathrm{m} \mathrm{m}^{-2} \mathrm{~s}^{-1}$ ) at a standardized distance. After this exposure, they were transferred again to the dark for $2 \mathrm{~h}$. Fluorescence traits were recorded on the disks, first in the dark, and afterwards six times: after incubation, after light exposure and every half hour during recovery. Fluorescence measurements were carried out at ambient $\mathrm{CO}_{2}$ and temperature on leaf disks with a Mini PAM fluorometer (Walz, Germany). Initial fluorescence $\left(\mathrm{F}_{0}\right)$ was measured by applying a pulse measuring red light $\left(<1 \mu \mathrm{mol} \mathrm{m} \mathrm{m}^{-2} \mathrm{~s}^{-1}\right)$ at a frequency of $1.6 \mathrm{kHz}$, and maximal fluorescence $\left(\mathrm{F}_{\mathrm{m}}\right)$ by an additional saturating flash of white light $\left(0.7 \mathrm{~s} ; 4000 \mu \mathrm{mol} \mathrm{m} \mathrm{m}^{-2} \mathrm{~s}^{-1}\right)$. The ratio of variable to maximal fluorescence $\mathrm{F}_{\mathrm{v}} / \mathrm{F}_{\mathrm{m}}$, that is the maximal PS II photochemical quantum yield, was calculated as: $\mathrm{F}_{\mathrm{v}} / \mathrm{F}_{\mathrm{m}}=1-\mathrm{F}_{0} / \mathrm{F}_{\mathrm{m}}$ (Genty et al., 1987).

\subsection{Statistical analyses}

Data management and statistical analyses were performed using SPSS software (SPSS, Chicago, IL). Means were expressed with their standard error $( \pm \mathrm{SE})$. Effects of leaf plastochron index and treatments were tested using the General Linear Model (GLM) procedure on linear parts of the profiles along the stem, separately. For the methyl-viologen experiment, comparisons in time and among concentrations were done using the GLM procedure for repeated measurements (Split Plot in Times). Differences between developmental stages and between genotypes were tested by an analysis of variance. All statistical tests were considered significant at $P \leqslant 0.05$.

\section{RESULTS}

\subsection{Leaf structure and growth}

The genotypes differed in terms of total leaf area, 'Luisa_Avanzo' showing a significantly larger leaf area than 'Dorskamp' (Fig. 1). Individual leaf area gradually increased till LPI 9 or 10 in both genotypes, reaching a larger final size 


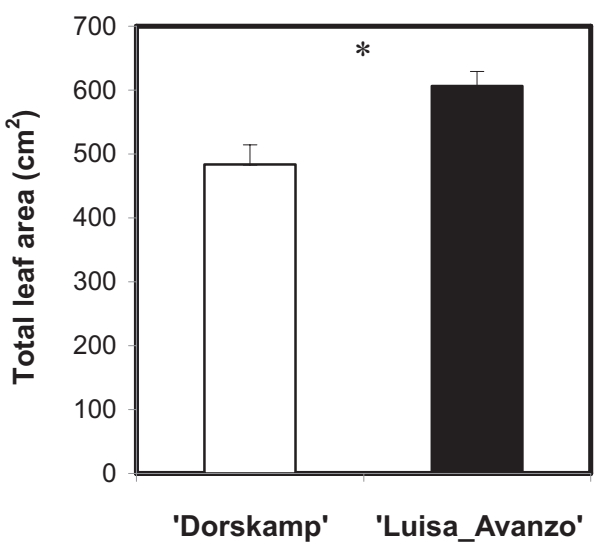

Figure 1. Total leaf area of 'Luisa_Avanzo' (black bar) and 'Dorskamp' (white bar). Means $( \pm \mathrm{SE}), n=10$ plants. Significant differences between genotypes are indicated by asterisks: $* P \leqslant 0.05$.

for 'Luisa_Avanzo' than for 'Dorskamp' at maturity (Fig. 2A). Then, leaf area decreased at LPI > 10 for 'Luisa_Avanzo' while it remained stable for 'Dorskamp'. The oldest leaves of both genotypes showed similar values. The trend was similar for SLA: increase till LPI 10 for 'Luisa_Avanzo' and LPI 5 for 'Dorskamp'; decrease in older leaves (LPI above 10, Fig. 2B). The two genotypes differed slightly with 'Dorskamp' displaying the highest SLA. Up to LPI 10, nitrogen and carbon contents decreased while chlorophyll content increased (Figs. 2C2 F). With LPI above 10, carbon and chlorophyll contents, as well as nitrogen expressed on a leaf area basis increased, while nitrogen content expressed on a dry weight basis slightly decreased. 'Luisa_Avanzo' exhibited significantly higher nitrogen and carbon contents than 'Dorskamp', and significantly lower chlorophyll contents.

\subsection{Leaf photosynthetic capacity}

All traits related to photosynthetic capacity were severely affected by leaf position on the stem (Fig. 2). Up to LPI 10, relative nitrogen allocation to RuBisCO $\left(\mathrm{P}_{\mathrm{R}}\right)$ and to bioenergetics $\left(\mathrm{P}_{\mathrm{B}}\right)$ increased (Figs. 3A and 3B). For LPI above 10, $\mathrm{P}_{R}$ and $\mathrm{P}_{B}$ remained stable. 'Luisa_Avanzo' exhibited significantly higher $\mathrm{P}_{\mathrm{R}}$ and $\mathrm{P}_{\mathrm{B}}$ than 'Dorskamp'. The ratio between maximal light driven electron flow $\left(\mathrm{J}_{\max }\right)$ and maximal apparent carboxylation rate $\left(\mathrm{V}_{\text {cmaxApp }}\right)$, and dark respiration $\left(\mathrm{R}_{\mathrm{d}}\right)$ decreased up to LPI 10 , while $\mathrm{V}_{\mathrm{cmaxApp}}$ and $\mathrm{J}_{\max }$ increased (Figs. 3C-3F). For LPI superior to $10, \mathrm{~J}_{\max } / \mathrm{V}_{\mathrm{cmax} \text { App }}$ and $R_{d}$ were stabilized, while $V_{c m a x A p p}$ slightly decreased. 'Luisa_Avanzo' exhibited significantly higher $\mathrm{V}_{\text {cmaxApp }}$ and $\mathrm{R}_{\mathrm{d}}$ than 'Dorskamp', and significantly lower $\mathrm{J}_{\max } / \mathrm{V}_{\text {cmaxApp }}$.

\subsection{Thermotolerance}

Critical temperature $\left(\mathrm{T}_{\mathrm{C}}\right)$ was around $45{ }^{\circ} \mathrm{C}$ for growing leaves. It gradually increased until LPI 10, and reached levels above $46{ }^{\circ} \mathrm{C}$ in older leaves. No clonal difference could be detected (Fig. 4).

\subsection{Tolerance to photo-oxidations}

Maximal PS II photochemical efficiency $\left(\mathrm{F}_{\mathrm{v}} / \mathrm{F}_{\mathrm{m}}\right)$ reached levels between 0.7 and 0.8 for leaf disks incubated in water under darkness (Fig. 5). In response to incubation with $20 \mu \mathrm{M}$ methyl-viologen, $\mathrm{F}_{\mathrm{v}} / \mathrm{F}_{\mathrm{m}}$ was significantly lower after exposure to light followed by dark-acclimation for the three leaf categories (expanding, young mature and old) of both genotypes $(P \leqslant 0.05)$. The response to methyl-viologen significantly differed between the three leaf categories $(P \leqslant 0.05)$, the irradiance induced decline of $\mathrm{F}_{\mathrm{v}} / \mathrm{F}_{\mathrm{m}}$ being larger for the young mature leaves than for the oldest as well as for the expanding ones $(P \leqslant 0.001)$ (Figs. 5E and 5F). In the dark, the oldest leaves recovered $\mathrm{F}_{\mathrm{v}} / \mathrm{F}_{\mathrm{m}}$ values close to controls. On the contrary, recovery was incomplete for expanding leaves and totally absent for young mature leaves of both genotypes. No significant genotypic difference could be observed for the sensitivity to methyl-viologen.

\section{DISCUSSION}

A narrow relationship appeared between leaf position on the stem and their structure and physiology. As poplars grow, successive leaves gradually increase their fully expanded area up to a maximum that is usually not reached during greenhouse experiments (Larson and Gordon, 1969; Marron et al., 2003). The variability along the stem was thus due to the combined effects of leaf ageing and ontogenic processes affecting the growing individual.

\subsection{Structural and physiological changes during leaf lifespan}

Under the growth conditions of this study, leaf expansion lasts about 15 days (Marron et al. 2003). Parallel to the increase in size, leaf density/thickness gradually decreases, which could be explained by the progression of cell enlargement (Marron et al., 2003; Van Volkenburgh and Taylor, 1996). Moreover, leaf chlorophyll content and the apparent fraction of leaf nitrogen invested into RuBisCO and into bioenergetics, and consequently photosynthetic capacity (estimated through apparent $\mathrm{V}_{\text {cmaxApp }}$ and the ratio $\mathrm{J}_{\max } / \mathrm{V}_{\mathrm{cmax} A p p}$ ) increased significantly. On the contrary, respiration and nitrogen content decreased during leaf expansion. Decrease in respiration as well as nitrogen contents during leaf growth had already been observed for a large range of tree species (Mediavilla and Escudero, 2003). Individual leaf expansion rates reach a maximum approximately one week after leaf emergence (Marron et al., 2003).

When final leaf size is reached, leaf density is usually minimal and photosynthetic capacity attains maximal levels (Schumaker et al., 1997). For poplar, it has already been observed that maximum photosynthetic capacities are reached around the third week of leaf development, at full leaf expansion (Reich, 1983; Coll et al., 2007). A negative relationship 

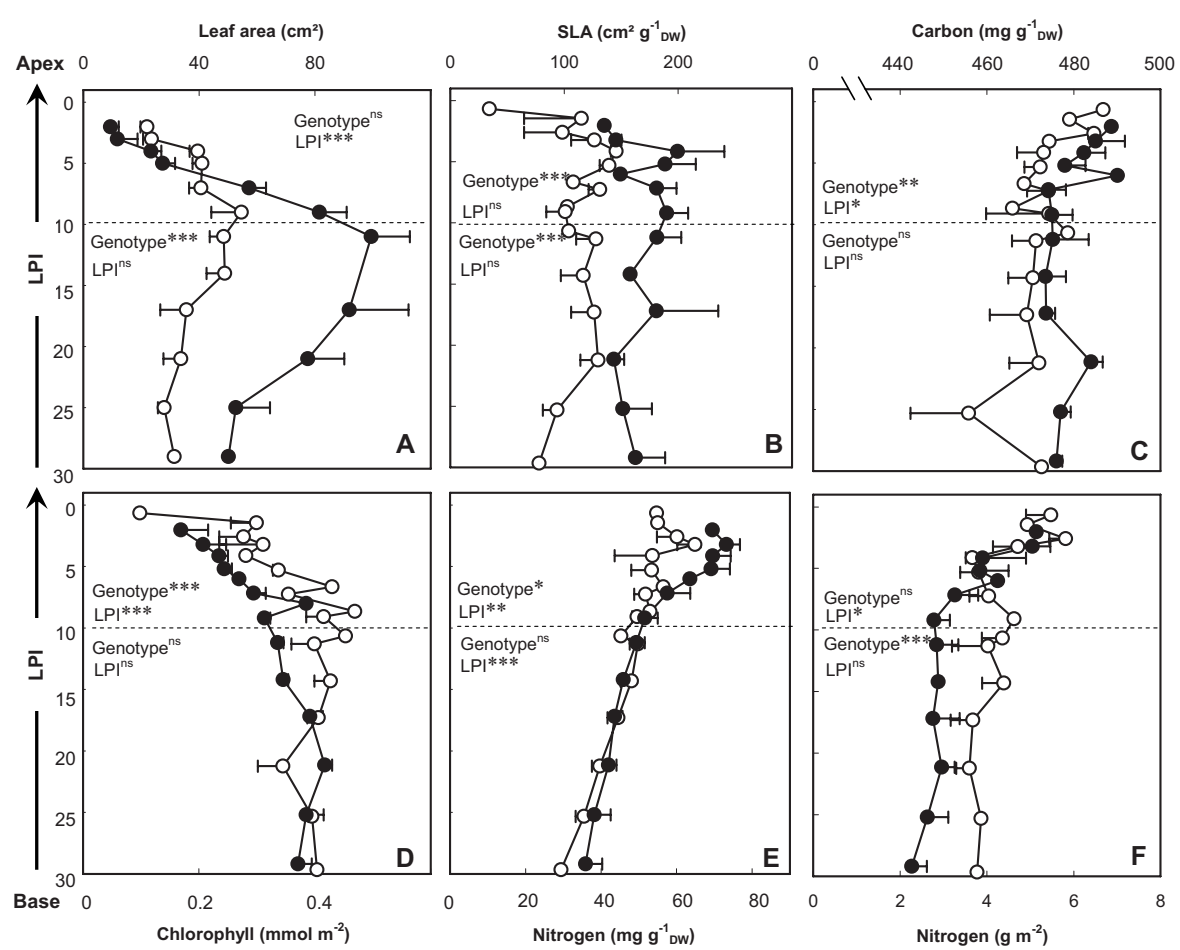

Figure 2. The effect of leaf position on the stem on leaf area (A), on SLA (B), on leaf carbon content (C), on leaf chlorophyll content (D), on leaf nitrogen content on a dry weight basis (E) and on an area basis (F) of plants of 'Dorskamp' (white) and 'Luisa_Avanzo' (black). Leaves are indexed from the top to the bottom of the stem. Means $( \pm \mathrm{SE}), n=5$ plants. The effects of LPI and treatment have been tested using a General Linear Model procedure dissociating LPI higher than 10 and lower than 10 . Significant effects are indicated by asterisks: $* \leqslant 0.05$, $* * P \leqslant 0.01, * * * P \leqslant 0.001$, and ns for non-significant.

between photosynthetic capacity and leaf density was also detected in a wide range of species (Niinemets, 1999). One possible reason for this relationship is an increase of photosynthetic capacity during leaf growth possibly induced by a decline of the diffusive resistance between the intercellular air spaces and the carboxylation sites with decreasing tissue density (Niinemets, 1999), and by the gradual construction of the photosynthetic apparatus by increasing nitrogen allocation to RuBisCO and increased chlorophyll contents.

During ageing, leaf density and thickness gradually increase (Marron et al., 2003; Niinemets, 2001). According to Niinemets et al. (2005), leaf dry mass per unit area increases with leaf ageing, and this can be considered as the major agedependent modification in leaf structure in evergreen species. Palisade and spongy parenchyma layers and epidermis thicken (Schumaker et al., 1997). Leaves accumulate soluble compounds such as sugars, phenols and mineral elements (Marron et al., 2002; Nelson and Isebrands, 1983). The density increase, partly due to an enhanced lignification during leaf ageing, causes a decline of photosynthetic capacity (Evans and Poorter, 2001). Reversely to the increase observed during leaf expansion, this decline can be partly explained by an increased resistance to $\mathrm{CO}_{2}$ transfer to the carboxylation sites, since neither the chlorophyll content nor the apparent nitrogen allocation to RuBisCO and to bioenergetics were significantly modified during leaf ageing. In several evergreen species, a large decrease of internal conductance was evidenced with leaf ageing (Niinemets et al., 2005). Moreover, as was observed for Pinus pinaster, a down-regulation of RuBisCO activity may occur with leaf age (Warren, 2006b). Nitrogen content per unit leaf area was not affected by leaf ageing while the nitrogen content per dry mass unit decreased, suggesting an accumulation of cell-wall components and corresponding dilution of foliar nitrogen rather than a net $\mathrm{N}$ re-translocation (Niinemets et al., 2005). Leaf senescence is known to involve a decrease of leaf density and a reduction of the photosynthetic capacity caused by the pigments, ions, proteins and sugars remobilization to the stem before leaf abscission (Marron et al., 2003).

\subsection{Impact of leaf age on the response to abiotic constraints}

High temperature-induced rise of ground fluorescence has been widely used as an indicator of thermal damage and correlates well with the temperature at which leaves experience significant tissue necrosis (Bilger et al., 1984). Dislocation between the light-harvesting complexes and photo-system (PS II) reaction centres due to excessive membrane fluidity is thought to cause this rise (Logan and Monson, 1999), although Yamane et al. (1997) suggested that denaturation of PS II reaction centre proteins may be involved as well. In our study, an increase of the tolerance to heat was observed with leaf ageing, 

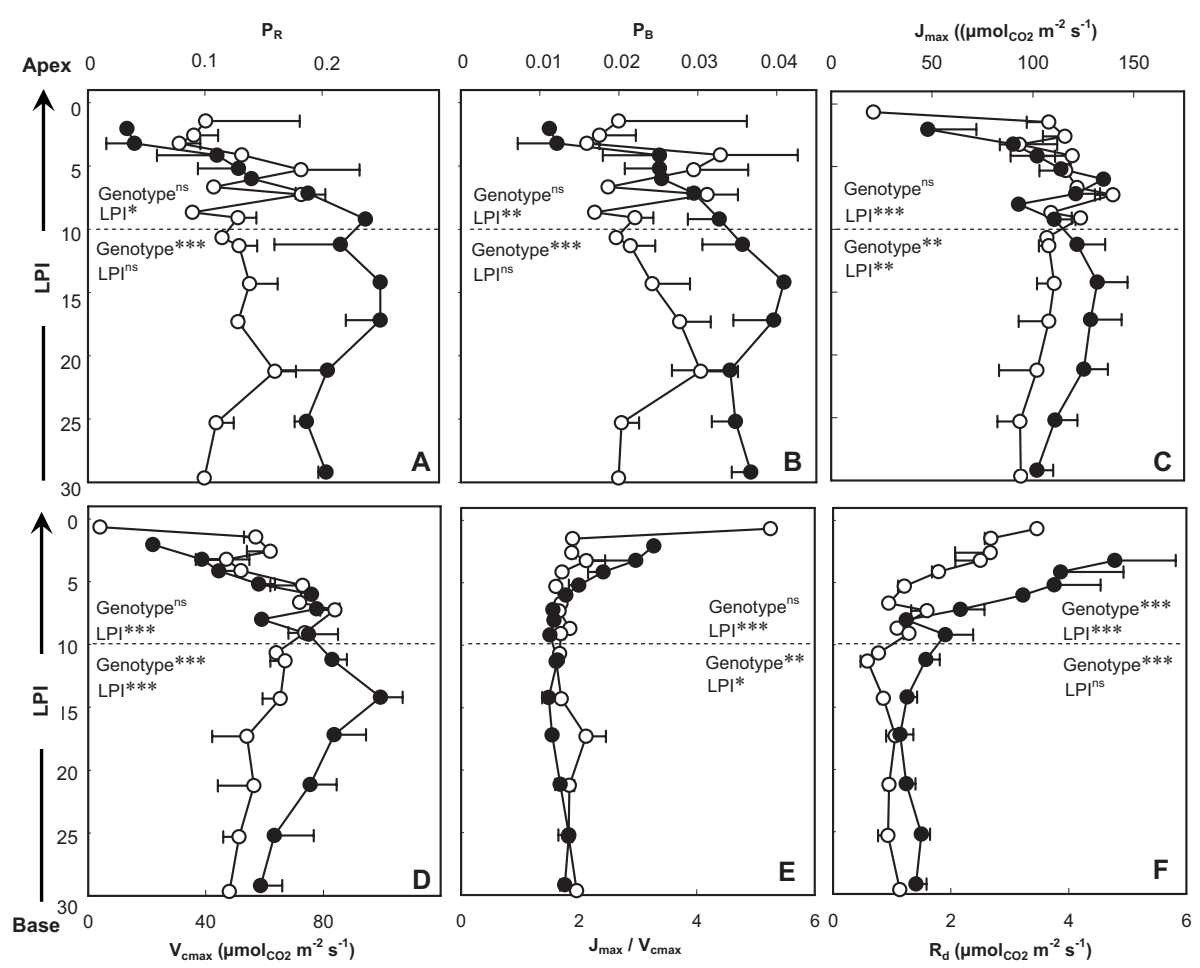

Figure 3. The effect of leaf position on the stem on proportion of leaf nitrogen in RuBisCO, $P_{R}(A)$, on proportion of leaf nitrogen in bioenergetics, $\mathrm{P}_{\mathrm{B}}(\mathrm{B})$, on maximal electron transport rate per unit leaf area, $\mathrm{J}_{\max }(\mathrm{C})$, on maximal apparent carboxylation rate per unit leaf area, $\mathrm{V}_{\mathrm{cmax} A p p}$ (D), on ratio between maximal electron transport rate and maximal apparent carboxylation rate, $\mathrm{J}_{\max } / \mathrm{V}_{\mathrm{cmaxApp}}(\mathrm{E})$, and on mitochondrial respiration rate, $\mathrm{R}_{\mathrm{d}}(\mathrm{F})$ of plants of 'Dorskamp' (white) and 'Luisa_Avanzo' (black). Leaves are indexed from the top to the bottom of the stem. Means $( \pm \mathrm{SE}), n=5$ plants. The effects of LPI and treatment have been tested using a General Linear Model procedure dissociating LPI higher than 10 and lower than 10 . Significant effects are indicated by asterisks: $* P \leqslant 0.05, * * P \leqslant 0.01, * * * P \leqslant 0.001$ and ns for non-significant.
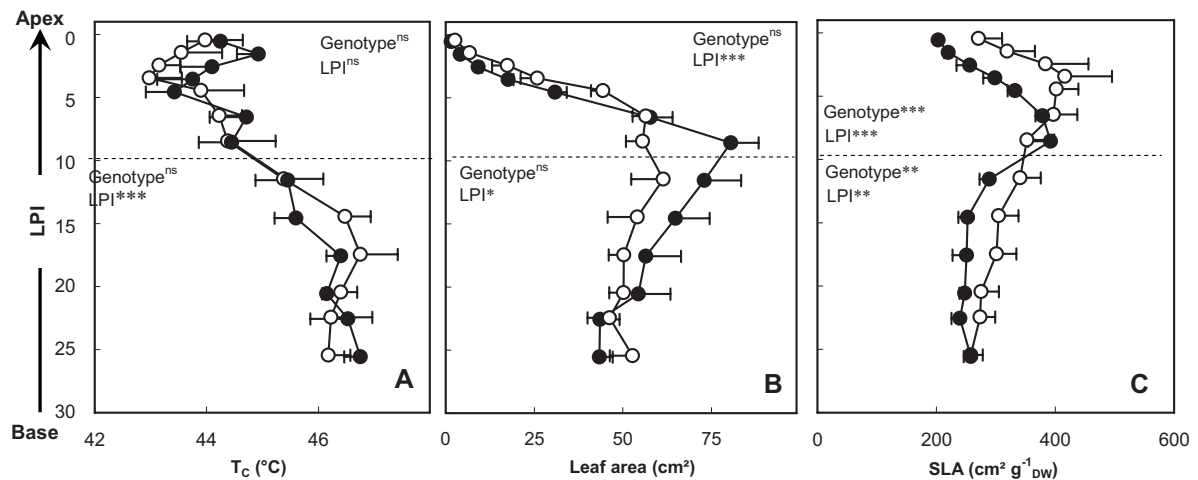

Figure 4. The effect of leaf position on the stem on critical temperature $\left(\mathrm{T}_{\mathrm{C}}, \mathrm{A}\right)$, on leaf area (B), and on SLA (C) of plants of 'Dorskamp' (white) and 'Luisa_Avanzo' (black). Leaves are indexed from the top to the bottom of the stem. Means ( \pm SE), $n=5$ plants. The effects of LPI and treatment have been tested using a General Linear Model procedure dissociating LPI higher than 10 and lower than 10. Significant effects are indicated by asterisks: $* P \leq 0.05, * * P \leq 0.01, * * * P \leq 0.001$ and ns for non-significant.

the oldest leaves being the most tolerant to high temperatures while the young mature ones were the most sensitive.

Exposure to various constraints is associated with oxidative damage at the cellular level (Smirnoff, 1993). Plant cells are normally protected against the detrimental effects of reactive oxygen species by a complex antioxidant system involving both enzymatic (superoxide dismutase, ascorbate peroxidase, catalase...) and non enzymatic detoxification mech- anisms (gluthatione, ascorbic acid, phenolic compounds...). For 'Luisa_Avanzo' and 'Dorskamp', it has already been shown that different antioxidant enzymes were stimulated in mature and expanding leaves in response to drought (Marron et al., 2006). On the other hand, for 'Luisa_Avanzo' only, the young mature leaves were the ones showing the lowest antioxidant activities and the lowest content in phenolic compounds under conditions of restricted supply of water (Marron et al., 


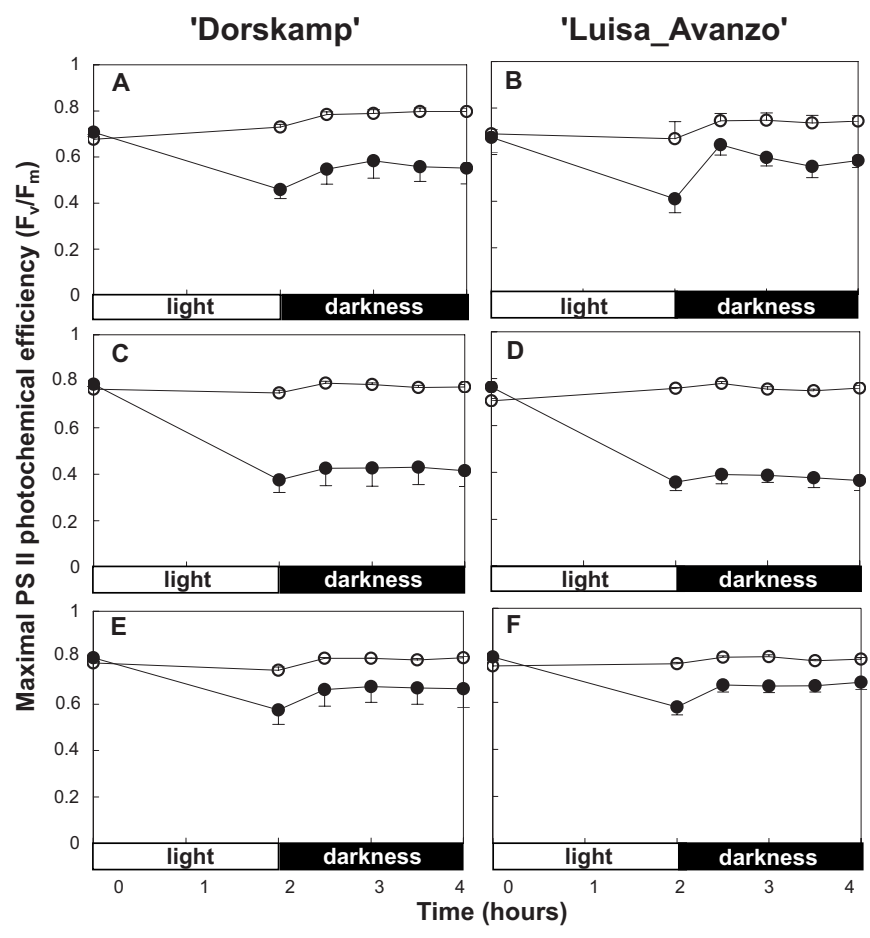

Figure 5. Time variations of maximal PS II photochemical efficiency $\left(\mathrm{F}_{\mathrm{v}} / \mathrm{F}_{\mathrm{m}}\right)$ for expanding (A and $\left.\mathrm{B}\right)$, young mature $(\mathrm{C}$ and $\mathrm{D})$ and mature leaves (E and F) of 'Dorskamp' and 'Luisa_Avanzo' subjected to distilled water (white) or $20 \mu \mathrm{M}$ methyl-viologen (black). Means $( \pm \mathrm{SE}), n=4$ plants.

2002). However, the previous results did not provide any clue about the degree of sensitivity of different leaf categories to oxidative stress. In the present study, no significant difference was observed among the different leaf categories in terms of stomatal conductance (data not shown) and, on this basis, we hypothesized that the penetration of the methyl-viologen into the leaf disks was similar in all leaf categories. Under this assumption, we showed that the young mature leaves were indeed the most sensitive to the oxidative constraint generated in vitro by application of methyl-viologen.

A large diversity of responses to environmental constraints was expected from the differences in leaf structure and physiology at various developmental stages. The low tissue density of young mature leaves may increase their sensitivity to stress conditions such as heat or oxidation generated by methylviologen. The gradual increase in leaf density and/or thickness causes an improvement of the leaf resistance to environmental constraints (Nautiyal et al., 2002). A strong relationship is often found between leaf lifespan and SLA across species, suggesting that the structural reinforcement of leaves plays a major role in determining their lifespan, presumably by rendering them less susceptible to environmental stress conditions (Wright and Cannon, 2001).

\section{CONCLUSIONS}

As already shown in earlier studies (Marron et al., 2002; 2003) and from field observations (Soulères, 1992),
'Dorskamp' and 'Luisa_Avanzo' greatly differ in terms of leaf growth, the latter being the most productive genotype. However, physiological traits exhibited larger differences between leaves of the same stem but at various development stages than among the two genotypes with different levels of productivity. Given the strong variability in leaf physiology related to age and position within the canopy, such effects require much attention when scaling leaf properties and leaf responses to environmental constraints from single leaves to higher hierarchical levels such as branch or tree scale.

We have chosen to focus our study on a relatively simple model composed of juvenile single stem plants grown under controlled conditions without limitation in terms of water, nitrogen, and light. Carbon partitioning patterns become more complicated as trees age because of the increasing complexity of crown morphology, and tree-level photosynthetic and other physiological gradients. Because of the experimental difficulties related to tree size and dimensions, little information is available for trees older than two years. Dickson (1986) postulated that a large Populus tree is basically a collection of developing one-year-old shoots. Thus, carbon flow and photosynthate partitioning follow essentially the same patterns in developing, mature, or senescing leaves whether on a developing seedling or on the current terminal shoot of a ten-year-old tree.

Acknowledgements: The authors thank for their help J.-M. Gioria, R. Bénardeau (plant material management), G. Moreau (technical assistance), J. Marchand (carbon and nitrogen analyses), Dr. F. Froux (thermotolerance estimation), and P. Gross (photosynthetic capacity assessment). We also thank Prof. R. Ceulemans for helpful comments on an earlier version of this manuscript. N. Marron was supported by a Ph.D. grant from the Conseil Régional, Région Centre, France.

\section{REFERENCES}

Bilger H.W., Schreiber U., and Lange O.L., 1984. Determination of leaf heat resistance: comparative investigation of chlorophyll fluorescence changes and tissue necrosis methods. Oecologia 63: 256-262.

Brignolas F., Thierry C., Guerrier G., and Boudouresque E., 2000. Compared water deficit response of two Populus $\times$ euramericana clones, Luisa Avanzo and Dorskamp. Ann. For. Sci. 57: 261-266.

Ceulemans R., 1990. Genetic variation in functional and structural productivity determinants in poplar. Thesis Publishers, Amsterdam.

Ceulemans R., Impens I., and Steenackers, V., 1988. Genetic variation in aspects of leaf growth of Populus clones, using the leaf plastochron index. Can. J. For. Res. 18: 1069-1077.

Ceulemans R. and Isebrands J.G., 1996. Carbon acquisition and allocation. In: Stettler R.F., Bradshaw, H.D. Jr., Heilman P.E., Hinckley T.M. (Eds.), Biology of Populus and its implications for management and conservation, NRC Research Press, National Research Council of Canada, Ottawa, pp. 355-392.

Coleman M.D., Dickson R.E., Isebrands J.G., and Karnosky D.F., 1996. Root growth and physiology of potted and field-grown trembling aspen exposed to tropospheric ozone. Tree Physiol. 16: 145-152.

Coll L., Messier C., Delagrange S., and Berninger F., 2007. Growth, allocation and leaf gas exchanges of hybrid poplar plants in their establishment phase on previously forested sites: effect of different vegetation management techniques. Ann. For. Sci. 64: 275-285. 
Dickmann D.I., 1971. Photosynthesis and respiration by developing leaves of cottonwood (Populus deltoides Bartr.). Bot. Gaz. 132: 253259.

Dickson R.E., 1986. Carbon fixation and distribution in young Populus trees. In: Fujimori, T., Whitehead, D. (Eds.), Crown and canopy structure in relation to productivity, forestry and forest products, Research Institute, Ibaraki, pp. 409-426.

Dreyer E., Le Roux X., Montpied P., Daudet F.A., and Masson F., 2001. Temperature response of leaf photosynthetic capacity in seedlings from seven temperate tree species. Tree Physiol. 21: 223-232.

Erickson R.O. and Michelini F.J., 1957. The plastochron index. Am. J. Bot. 44: 297-305.

Evans J.R. and Poorter H., 2001. Photosynthetic acclimation of plants to growth irradiance: the relative importance of specific leaf area and nitrogen partitioning in maximizing carbon gain. Plant Cell Environ. 24: 755-767.

Froux F., Ducrey M., Epron D., and Dreyer E., 2004. Seasonal variations and acclimation potential of the thermostability in four Mediterranean conifers. Ann. For. Sci. 61: 235-241.

Genty B., Briantais J.M., and Baker N.R., 1987. The relationship between the quantum yield of photosynthetic electron transport and quenching of chlorophyll fluorescence. Biochim. Biophys. Acta 990: 87-92.

Gonzalez-Real M.M. and Baille A., 2000. Changes in leaf photosynthetic parameters with leaf position and nitrogen content within a rose plant canopy (Rosa hybrida). Plant Cell Environ. 23: 351-363.

Isebrands J.G. and Larson P.R., 1977. Organization and ontogeny of the vascular cambium in the petiole of eastern cottonwood. Am. J. Bot. 64: 65-77.

Larson P.R. and Gordon J.C., 1969. Leaf development, photosynthesis and ${ }^{14} \mathrm{C}$ distribution in Populus deltoides seedlings. Am. J. Bot. 56 $1058-1066$.

Larson P.R. and Isebrands J.G., 1971. The plastochron index as applied to developmental studies of cottonwood, Can. J. For. Res. 1: 1-11.

Logan B.A. and Monson R.K., 1999. Thermotolerance of leaf disks from four isoprene-emitting species is not enhanced by exposure to exogenous isoprene. Plant Physiol. 120: 821-825.

Marron N., Delay D., Petit J.-M., Dreyer E., Kahlem G., Delmotte F.M., and Brignolas F., 2002. Physiological traits of two Populus $\times$ euramericana clones, Luisa Avanzo and Dorskamp, during a water stress and re-watering cycle. Tree Physiol. 22: 849-858.

Marron N., Dreyer E., Boudouresque E., Delay D., Petit J.-M., Delmotte F.M., and Brignolas F., 2003. Impact of successive drought and rewatering cycles on growth and specific leaf area of two Populus $\times$ canadensis (Moench) clones, 'Dorskamp' and 'Luisa_Avanzo'. Tree Physiol. 23: 1225-1235.

Marron N., Maury S., Rinaldi C., and Brignolas F., 2006. Impact of drought and leaf development stage on enzymatic antioxidant system of two Populus deltoides $\times$ nigra clones. Ann. For. Sci. 63: 323-327.

McKinney G., 1941. Absorption of light by chlorophyll solutions. J. Biol. Chem. 140: 315-322.

Mediavilla S. and Escudero A., 2003. Photosynthetic capacity, integrated over the lifetime of a leaf, is predicted to be independent of leaf longevity in some tree species. New Phytol. 159: 203-211.

Miyazawa S.-I. and Terashima I., 2001. Slow development of leaf photosynthesis in an evergreen broad-leaved tree, Castanopsis sieboldii: relationships between leaf anatomical characteristics and photosynthetic rate. Plant Cell Environ. 24: 279-291.

Nautiyal P.C., Rachaputi N.R., and Joshi Y.C., 2002. Moisture-deficitinduced changes in leaf-water content, leaf carbon exchange rate and biomass production in groundnut cultivars differing in specific leaf area. Field Crop. Res. 74: 67-79.

Nelson N.D. and Isebrands J.G., 1983. Late-season photosynthesis and photosynthetate distribution in an intensively cultured Populus nigra $\times$ laurifolia clone. Photosynthetica 17: 537-549.

Niinemets Ü., 1999. Research review. Components of leaf dry mass per area - thickness and density - alter leaf photosynthetic capacity in reverse directions in woody plants. New Phytol. 144: 35-57.

Niinemets Ü., 2001. Global-scale climatic controls of leaf dry mass per area, density, and thickness in trees and shrubs. Ecology 82: 453469.

Niinemets Ü., and Tenhunen J.D., 1997. A model separating leaf structural and physiological effects on carbon gain along light gradients for the shade-tolerant species Acer saccharum. Plant Cell Environ. 20: $845-866$.

Niinemets Ü., Cescatti A., Rodeghiero M., and Tosens T., 2005. Leaf internal diffusion conductance limits photosynthesis more strongly in older leaves of Mediterranean evergreen broad-leaved species. Plant Cell Environ. 28: 1552-1566.

Reich P.B., 1983. Effects of low concentrations of $\mathrm{O}_{3}$ on net photosynthesis, dark respiration, and chlorophyll contents in aging hybrid poplar leaves. Plant Physiol. 73: 291-296.

Schumaker M.A., Bassman J.H., Robberecht R., and Radamaker G.K., 1997. Growth, leaf anatomy, and physiology of Populus clones in response to solar ultraviolet-B radiation. Tree Physiol. 17: 617-626.

Smirnoff N., 1993. The role of active oxygen in the response of plants to water deficit and desiccation. New Phytol. 125: 27-58.

Soulères G., 1992. Les milieux de la populiculture. IDF, Paris.

Van Arendonk J.J.M.C. and Poorter H., 1994. The chemical composition and anatomical structure of leaves of grass species differing in relative growth rate. Plant Cell Environ. 17: 963-970.

Van Volkenburgh E. and Taylor G., 1996. Leaf growth physiology. In: Stettler R.F., Bradshaw H.D.Jr, Heilman P.E., Hinckley T.M. (Eds.), Biology of Populus and its implications for management and conservation, NRC Research Press, National Research Council of Canada, Ottawa, pp. 283-299.

Warren C.R., 2006a. Estimating the internal conductance to $\mathrm{CO}_{2}$ movement. Funct. Plant Biol. 33: 431-442.

Warren C.R., 2006b. Why does photosynthesis decrease with needle age in Pinus pinaster? Trees 20: 157-164.

Wright I.J. and Cannon K., 2001. Relationships between leaf lifespan and structural defences in a low-nutrient, sclerophyll flora. Funct. Ecol. 15: $351-359$.

Yamane Y., Kashino Y., Koike H., and Satoh K., 1997. Increases in the fluorescence $F_{0}$ level and reversible inhibition of photosystem II reaction center by high-temperature treatments in higher plants. Photosynth. Res. 52: 57-64.

Zelawski W. and Walker R.B., 1976. Photosynthesis, respiration, and dry matter production. In: Miksche J.P. (Ed.), Modern methods of forest genetics, Springer-Verlag, New York, pp. 89-119. 